\title{
O szczególnych powinowactwach literatury i kina w refleksji Stefanii Zahorskiej
}

\begin{abstract}
Hendrykowska Małgorzata, O szczególnych powinowactwach literatury i kina $w$ refleksji Stefanii Zahorskiej [Particular Affinities between Literature and Film in Stefania Zahorska's Reflections]. „Przestrzenie Teorii” 32. Poznań 2019, Adam Mickiewicz University Press, pp. 167-178. ISSN 1644-6763. DOI 10.14746/pt.2019.32.8.

The author provides an in-depth analysis of and original essay written by the Polish film critic Stefania Zahorska in the middle of the 1930s. The essay deals with socio-cultural and aesthetic theory regarding the mutual connections between cinema and literature.
\end{abstract}

KEYWORDS: Stefania Zahorska, aesthetics, cinema, film, literature, novel, narration, theory of creative practice, comparatistics, adaptation, art, modern culture

Jest rok 1934. Kinematografia polska - ta „przedniepodległościowa”, wojenna i ta, którą budowano niemal od podstaw po odzyskaniu niepodległości, a więc kinematografia od blisko ćwierćwiecza, na wszelkie możliwe sposoby korzysta z bogactwa literatury. Najczęściej - i jest to fakt dość powszechnie znany - wiąże się to z chęcią uzyskania konkretnych pożytków: wsparcia się na znanym nazwisku, tytule literackim, ciekawej fabule, anegdocie... Trudno się więc dziwić, że w ogólnym odczuciu kinematografia polska - i tu przywołajmy ulubione sformułowania intelektualistów z lat dwudziestych i trzydziestych - „traktowała film pasożytniczo”, „była jemioła i hubą na zdrowym organizmie literatury". Nie zamierzam jednak w tym miejscu po raz kolejny podejmować rozważań na temat filmowych adaptacji utworów literackich.

Przedmiotem mojego zainteresowania jest unikatowej wartości studium krytyczne autorstwa Stefanii Zahorskiej zatytułowane: Co powieść zawdzięcza filmowi?, a opublikowane na łamach „Kuriera Literacko-Naukowego" (cotygodniowego dodatku do „Ilustrowanego Kuriera Codziennego”) w roku $1934^{1}$.

Ten niewielkich rozmiarów esej krytyczny - stanowczo zbyt rzadko eksponowany i przywoływany przez badaczy, co dzisiaj widać ze szczególną

${ }^{1}$ S. Zahorska, Co powieść zawdzięcza filmowi? „Kurier Literacko-Naukowy” 1934, nr 29. 
wyrazistością - pozostaje jednym z najciekawszych i najbardziej nośnych intelektualnie osiąnięć polskiej myśli filmowej dekady lat trzydziestych ${ }^{2}$.

Stawia on, poprzez swoja „odwrotność”, a więc skupienie się nie na tym, co film zawdzięcza literaturze, ale - przeciwnie - co literatura zawdzięcza filmowi, niezwykle interesujace pytania i otwiera pola ciekawych zagadnień badawczych. Po pierwsze, jaki charakter i jakie właściwości ma, w świetle oryginalnych poglądów krytycznych Stefanii Zahorskiej zaprezentowanych w studium pt. Co powieść zawdzięcza filmowi?, relacja (splot funkcjonalnych powiązań) między kinem a literaturą? Po drugie, czy zależność między nimi można uchwycić i opisać poza domena samej adaptacji, w kategoriach metapoetyki oraz estetyki słowa i ruchomego obrazu? I po trzecie, co istotnego, według autorki studium, wynika $\mathrm{z}$ dynamicznego rozwoju zmiennych form tej relacji dla kultury współczesnej: w jej wersji zarówno awangardowo-artystycznej, jak i popularnej?

Pytania te można jeszcze rozszerzyć o metodologiczną z istoty swej kwestię sposobu ujęcia problematyki zależności i powinowactw między obiema dziedzinami. Czy ujęcie takie ma się ograniczać wyłącznie do wąskozakresowej problematyki samej tylko adaptacji w układzie film - pierwowzór literacki, co niestety skutecznie ogranicza spojrzenie na związki kina i literatury? Czy też w sposobie pojmowania owych związków można wyjść poza krag problematyki stricte adaptacyjnej, poszerzywszy go o alternatywny zespół zagadnień wykraczających poza dyskurs na temat podobieństw i różnic między ekranizacją a pierwowzorem?

Zahorska opowiada się zdecydowanie za tym drugim wariantem. Z zasady nie wspomina więc o takich czy innych ekranizacjach dzieł literackich, a także nie rozpatruje wartościująco, czy są one względem nich „wierne” czy „niewierne”. Dlaczego? Czy chodzi o świadomie wykonany unik? Bynajmniej. W swoim tekście (podobnie jak w innych publikacjach o charakterze publicystycznym czy krytyczno-filmowym ${ }^{3}$ ) nie tuszuje przecież ujemnych właściwości produktów kinematograficznych i wystawia kinu wysoki rachunek za lata barbarzyńskiego wyrębu drzewostanu literatury, w pełni świadoma negatywnych skutków takiej rabunkowej gospodarki przemysłu filmowego. Pisze na ten temat następująco:

Z polskiej literatury mało kto uszedł naiwnej i dzikiej zachłanności filmu - nie uchronili się przed nią ani Mickiewicz, ani Sienkiewicz, ani Żeromski, jak i wielu innych. I literatura drogo płaciła za te pożyczki i przeróbki. Oblicze jej ukazywało

${ }^{2}$ Ostatnio opublikowała ten tekst Anna Nasiłowska [w:] Stefania Zahorska, Wybór pism reportaże, publicystyka, eseje, wybór, wstęp i oprac. A. Nasiłowska, Warszawa 2010, s. 285-290.

${ }^{3}$ Zob. m.in.: S. Zahorska, Rozbój filmowy, „Wiadomości Literackie” 1936, nr 50 (682), s. 2, w którym atakuje Polską Akademię Literatury oraz inne „władze” i organy literackie za „wyniosłą obojętność”, z jaką odnoszą się do sprawy „filmowych przeróbek”. 
się na ekranie tak wykoślawione, jak w krzywym zwierciadle, tak zgrubiałe, jak twarz pijaka - jej myśli delikatne i misterne w ekranowych obrazach przekształciły się w postronki, w wiechcie słomy. Literatura zaiste drogo płaciła i płaci za pracę wychowawcza nad filmem. Ale o tym wszystkim już wiemy. O tym nie trzeba już więcej mówić4

Jak widać, autorka - zmierzając do wynegocjowania całkiem odmiennego, bilateralnego i partnerskiego modelu koegzystencji obu dziedzin - wcale nie unika krytycznej refleksji nad filmem w kontekście jego związków z literatura. Nie zamierza tylko po raz kolejny rozprawiać o grzechach i ułomnościach lustrzanych odzwierciedleń (włącznie z deformacjami), jakie z reguły dają o sobie znać między ekranizacją a jej pierwowzorem. Z tego względu, raz odnotowawszy negatywne skutki uprawiania takiego procederu przez większość filmowców sięgających po dzieła literackie, konsekwentnie unika w swym studium wykorzystywania zarówno utartych porównań, jak i przykładów mających świadczyć o prostactwie i prymitywizmie kina.

Dostrzega natomiast wyrazowy potencjał sztuki ruchomych obrazów i nie uznaje kina za cośs skazanego na artystyczna miałkość i małość. Przywołane w tekście ironicznie określenia w rodzaju „młody urwipołeć”, „nieokrzesany dzikus”, „zaraza”, „naiwna i dzika zachłanność” etc. należą do porządku przytoczeń „cudzej mowy”. Uwalniając się od nich, Zahorska jasno dostrzega rozmaite słabości procederu adaptowania. Nie twierdzi jednak, że film stanowi tym samym odmianę twórczości z istoty swej gorszą od wykształconej siostry literatury, od jej finezji, artystycznej pełni i wyrafinowanej dojrzałości sztuki słowa, którą scenarzysta, reżyser i producent na mocy niepisanej reguły nieuchronnie gubia.

W analizowanym studium Stefanię Zahorska nurtuje natomiast inne, o wiele bardziej intrygujace pytanie dotyczące generalnie relacji film - literatura. A mianowicie, czy zależność między obiema dziedzinami przebiega wyłącznie jednokierunkowo: to znaczy od literatury w stronę filmu. Pogląd ten, od dawna ugruntowany, kursował wówczas i utrzymywał się w obiegowym przekonaniu na prawach powszechnie głoszonej oczywistości. Co więcej, miał on swoich zagorzałych zwolenników jeszcze w latach sześćdziesiątych ubiegłego stulecia, głoszących tezę o przyliterackości sztuki filmowej.

Czy zatem film tylko eksploatuje na swe potrzeby rozmaite utwory i formy literackie? Czy też nawiązana w najdawniejszych początkach istnienia kinematografii bliska relacja i pewna zażyłość, w której kino i literatura od pewnego czasu pozostaja, daje o sobie znać również w przeciwnym kierunku oddziaływania: biegnac od praktyk narracyjnych kina ku zmianom

${ }^{4}$ Ten i następne cytaty pochodzą z artykułu Stefanii Zahorskiej: Co powieść zawdzięcza filmowi? „Kurier Literacko-Naukowy” 1934, nr 29. 
zachodzącym w praktyce narracji literackiej, ze szczególnym podkreśleniem inspiracji filmowych dotyczących prozy powieściowej?

Kluczową rolę odgrywa w tym przypadku jedno spostrzeżenie. Okazuje się, że trakt krytycznofilmowy, który kreśli i którym podąża w swoim studium Zahorska, wytyczony zostaje w kierunku odwrotnym niż powszechnie przyjęte rozumowanie. W oczach krytyków i teoretyków (z wyjątkiem Karola Irzykowskiego ${ }^{5}$ ) to literatura od dawna dostarcza i daje coś cennego filmowi. Bez wzajemności, co mu się nieustannie wytyka. To z literatury filmowcy czerpią pełnymi garściami i ograbiaja ją nieustannie z głębszych wartości, spłycając adaptowane pierwowzory $\mathrm{w}$ nieudanych $\mathrm{z}$ reguły ekranizacjach. $\mathrm{W}$ stosunku do literatury kino jest więc kimś w rodzaju notorycznie niewypłacalnego dłużnika. Nieco inaczej wygląda ta kwestia w oczach samych artystów - o czym za chwilę, bowiem interesują nas w tym miejscu przede wszystkim rozważania krytyczne Stefanii Zahorskiej wokół relacji film literatura.

Autorka artykułu Co powieść zawdzięcza filmowi?, skądinąd doskonale zdając sobie sprawę z niezaprzeczalności faktu wieloletniego żerowania przemysłu filmowego na literaturze, przeprowadza zaskakujący, przeciwny w swej wymowie, dowód na czerpanie określonych wartości przez literaturę z filmu. Takie ujęcie problematyki powinowactw łączacych obie dziedziny i taka postawa to ewenement w skali nie tylko krajowej. Oznacza ona bowiem pojawienie się w systemie świadomości filmowej tamtego miejsca i czasu nowego typu oryginalnej refleksji krytycznej zainteresowanej czymśs innym i czymś więcej, niż wąsko pojęta problematyka adaptacji.

Wprowadźmy w tym miejscu pewną dygresję. Owa, „odwrotność” od myślenia wyłącznie adaptacyjnego w relacji literatura - film pierwsi zauważyli sami twórcy: malarze, graficy, prozaicy i poeci... Tuż po odzyskaniu przez Polskę niepodległości, w odmiennej sytuacji społecznej i kulturowej, zwłaszcza artyści związani z szeroko rozumianą awangarda, dostrzegli w filmie i kinie nowy impuls dla kultury. Pociagający był już sam fakt opozycyjności filmu i kina wobec tradycyjnej kultury, trywialność gustów, pomysłów, schematów filmowych tak odległych od konwencji tradycyjnie rozumianej sztuki. Wpływ kina stanie się coraz bardziej wyraźny w literaturze (Czyżewski, Jasieński, Młodożeniec, Stern, Brzękowski, Kurek, Peiper, Tuwim, Wierzyński i in.), malarstwie i muzyce. Począwszy od fascynacji niektórymi

${ }^{5}$ Równo dekadę przed ukazaniem się omawianego artykułu Stefanii Zahorskiej, na kartach książki Dziesiata Muza. Zagadnienia estetyczne kina (Kraków 1924) Karol Irzykowski zaprezentował w rozdziałach: XVII („Literaturofobia”), XX („Znaczenie fragmentu”), XXI (,Fotogenia”) oraz XXIV (,Reforma scenariusza”) własną koncepcję związków łączących film z literatura, opartą na idei odmienności mediów i własnych swoistych środków wyrazu każdej ze sztuk. 
tematami czy wręcz konkretnymi filmami ${ }^{6}$, a skończywszy - co dużo rzadsze - na powieści ukształtowanej na wzór filmu?

Przywołany wcześniej Karol Irzykowski i dziesięć lat później Stefania Zahorska patrza na to zjawisko szerzej, z perspektywy teoretyka i krytyka. Nie interesuja ich pojedyncze rozwiązania, indywidualne wybory. Z jednej strony mają ostrą świadomość kina jako „sztuki pasożytniczej” (określenie autora Dziesiatej Muzy - M.H.), a z drugiej, dążąc do zaprojektowania odmiennego modelu relacji funkcjonalnych między filmem a literatura, upatrują w sztuce ruchomych obrazów istnienia potencjału estetycznego zdolnego nie tylko obsłużyć potrzeby własne kina, ale również twórczo oddziaływać na przemiany współczesnej prozy powieściowej.

Spostrzegawczy czytelnik zauważył zapewne, że artykuł Co powieść zawdzięcza filmowi? raz nazywam „studium”, a kiedy indziej naprzemiennie „esejem krytycznym” bądź „esejem”. Wbrew pozorom, nie ma w tej alternacji sprzeczności; oba określenia użyte w tym kontekście nie wykluczaja się, lecz dopełniają się wzajemnie. Dają tu o sobie znać połączone w jedno dwie strategie pisarskiego dyskursu podporządkowane temu samemu celowi, a mianowicie: funkcji poznawczej pisarstwa krytycznego.

Kluczem do zrozumienia zachodzących w prozie współczesnej pod wpływem kina procesów nie jest dla Zahorskiej wędrówka takich czy innych tematów, ani kursowanie motywów czy matryc fabularnych. Istotę tego intrygującego fenomenu, w którym literatura nieoczekiwanie okazuje się biorca, stanowi - według niej - praktyka narracyjna obu dziedzin. Przedmiotem transferu okazuje się więc analogiczny sposób kształtowania fikcji ekranowej i powieściowej nastawiony na poszukiwanie nowych modeli percepcji i symbolicznych dróg przeżywania rzeczywistości inspirowanych przez sztukę ruchomego obrazu.

To nie jest abstrakcyjny teoremat. Raczej próba wykładu na temat przenikania się współczesnej prozy powieściowej i filmu - autorstwa osoby wszechstronnie wykształconej, oczytanej i gruntownie zorientowanej w nowych i najnowszych trendach światowego kina. Wytrawny krytyk sztuki, jakim była Stefania Zahorska, korzystając z przypisanej poetyce eseju swobody subiektywnego przeprowadzania wywodu i posługiwania się wachlarzem -

${ }^{6}$ Por. m.in. liczne odwołania do Gabinetu doktora Caligari w wierszu Antoniego Słonimskiego Negatyw (1921); motyw tego samego filmu w obrazie Karola Hillera Somnambulik, a także wiersze poświęcone konkretnym aktorom, np. Romana Kołonieckiego Harold Lloyd, Lucjana Faleńskiego Charlie Chaplin i in.

${ }^{7}$ Zapewniał o tym Jalu Kurek, pisząc we Wspomnieniach, że jego debiutancka powieść Kim byt Andrzej Panik? Andrzej Panik zamordowat Amundsena (1926) „pisana była w pewnym sensie techniką filmową”. Zob. J. Kurek, Wspomnienia ze straży przedniej, „Kwartalnik Filmowy" 1961, nr 3, s. 58, oraz m.in. M. Giżycki, Walka o film artystyczny w międzywojennej Polsce, Warszawa 1989, s. 18. 
dalece odmiennych niż rutynowo stosowane przez innych - odkrywczych argumentów w formie przykładu (zwłaszcza nieukrywana fascynacja poetycką urodą prozy Brunona Schulza!), wykorzystuje bowiem obok kunsztu literackiego także inny swój talent - wykładowczyni akademickiej.

Skoro już poruszone zostało zagadnienie swoistości krytyczno-filmowego dyskursu, jaki uprawiała w tamtych latach Stefania Zahorska, należy zauważyć, że za naturalne uznaje ona jako krytyk uteoretycznienie podejmowanych rozważań. Teoretyzuje jednak w takim tylko stopniu, który w żaden sposób nie usztywnia biegu rozważań. Wręcz przeciwnie, poszczególne swoje obserwacje i wyprowadzane z nich uogólnienia czyni otwartymi. Zabieg ten sprawia, że adresat eseju zostaje wciagnięty w intrygujący dialog racji z jego autorka.

Spróbujmy przyjrzeć się bliżej pod tym kątem drugiemu akapitowi analizowanego artykułu. Rozpoczyna go takie zdanie:

Kiedy ludzi przestała zachwycać sama ruchliwość obrazów na ekranie, sam fakt, że widzą psa machającego ogonem - okazało się, że trzeba o wiele metrów podnieść poziom kulturalny filmu, by w ogóle stał się strawny. I któż to miał zrobić, kto miał spełnić tę ciężką pracę wychowawczą? Oczywiście, zaprzątnięto do roboty literaturę.

Punkt wyjścia całego rozumowania zawiera sylogizm tyleż obiegowy, co oczywisty. Nieporadnie raczkujaccy, głupiutki kinematograf - i wyciagająca w jego stronę pomocna dłoń dojrzała literatura. Dodajmy, że ów schemat myślowy został zaprezentowany nader prosto i obrazowo, jak przystało na artykuł publikowany nie w elitarnym piśmie naukowym waskiego obiegu, lecz w popularnym dzienniku, jakim był „Ilustrowany Kurier Codzienny”.

Ciekawe okazuje się dopiero rozwinięcie wyjściowego stereotypu. $\mathrm{Na}$ temat przebiegu dalszych związów kina z literaturą Stefania Zahorska pisze następująco:

Wkroczyła w życie filmu dwukrotnie: raz na samym początku, dając mu pierwszy zastrzyk treści i sensu - kiedy to w niemych jeszcze wersjach filmowano wielkie powieści historyczne, jak Quo vadis i Ostatnie dni Pompei, kiedy na wzór naturalistycznych powieści z końca XIX wieku klecono filmowe opowieści o upadłych dziewczynach lub z detektywistycznych romansów brano bardziej już związaną i logiczną budowę policyjnych dramatów filmowych.

Moment później w rozważaniach autorki następuje bardzo znamienny i doniosły zwrot, który czyni cytowany artykuł nie tylko głosem w tamtym czasie osobnym i wyjątkowym, ale także - dziś widać to szczególnie wyraź-

${ }^{8}$ Docent Stefania Zahorska była przez szereg lat wykładowczynia przedmiotów z zakresu historii i teorii sztuki dla słuchaczy Wolnej Wszechnicy Polskiej w Warszawie. WWP była czterowydziałową uczelnią prywatną utworzoną w roku 1918; specjalizowała się w naukach społecznych. 
nie - prekursorskim w sposobie widzenia głębszych relacji filmu i literatury. Oto bowiem Zahorska bierze kino traktowane jak krnąbrny i niesforny „chłopiec do bicia” w obronę przed surowymi krytykami, mówiąc:

Kto wie nawet, czy niejednokrotnie nie skrzywdzili filmu, czy nie przeoczyli pewnych jego cennych właściwości. Tych mianowicie, które niezależnie od rekordowej głupoty scenariuszy i inscenizacji wprowadzają jednak jakąś odrębną nutę w widzenie świata, sa jednak nowym i swoistym ustosunkowaniem się do rzeczywistości - tak nowym, że niedostępnym dla innych sztuk. Tak jest - istnieją i takie dziedziny, w których nieokrzesany dzikus - film - przoduje. W których jest w stanie zafascynować nawet o tyle od siebie mędrszą literaturę. W których sugestia jego roztacza się niemal hipnotycznie i tak mocno, że wżera się po prostu w karty pisanych książek. Tak, film wywiera niewątpliwie wpływ na literaturę, i to nie tylko na teatr - nawet na powieść.

Zastanawiające, że Zahorska w ogóle nie nawiązuje w swych rozważaniach na temat relacji film - literatura do fenomenu powieści filmowej i ani razu nie powołuje się w swoim tekście na negatywnie bądź pozytywnie oceniany przykład którejś z nich. Na pierwszy rzut oka mógłby to przecież być poręczny i mocny argument na rzecz czerpania z kina przez prozę powieściowa. Dlaczego nie? Czyżby osoba tak oczytana i doskonale zorientowana w rynku wydawniczym w ogóle nie wiedziała o istnieniu i niemałej poczytności tego typu, krażących w obiegu popularnym, wysokonakładowych - literackich, czy jak kto woli paraliterackich - produkcji, którymi w tamtym czasie parali się między innymi: Leo Belmont (Człowiek, z którego świat się śmieje, Niepotrzebny człowiek, 1928), Zofia Dromlewiczowa (Pod bandera miłości, 1929; Pod dachami Paryża, 1930) oraz grono innych autorów.

Nie sądzę. Chodzi raczej o coś innego. Autorka zdaje sobie sprawę, że samo zjawisko tak zwanej powieści filmowej, choć na swój sposób czytelniczo i kinomańsko atrakcyjne, ma jednak w systemie kultury charakter efemeryczny, wtórny i generalnie jest świadectwem zaledwie powierzchownej i nad wyraz płytkiej relacji kina z literatura. Zahorską interesuje natomiast traktowany przez nią systemowo - problem głębokich zmian zachodzących w strukturze narracyjnej utworów filmowych i powieściowych. Słowem nie substancja, lecz pełniona tu i tam funkcja estetyczna i poznawcza.

Jeśli głębiej wniknąć w sposób modelowania relacji między literatura a filmem i vice versa prezentowany przez autorkę artykułu Co powieść zawdzięcza filmowi?, można dojść do wniosku, że zauważona wyżej nieobecność w nim powieści filmowej wynika całkiem logicznie z samej istoty wypracowanej koncepcji.

Otóż, powieść filmowa, mimo że na pozór stanowi świadectwo bardzo żywej zależności ruchomych obrazów i słowa, w świetle koncepcji Stefanii Zahorskiej z góry odpada jako odpowiednio mocny argument. Sam wymowny 
wybór tytułów „upowieściowionych” filmów przez Belmonta, Dromlewiczowa i innych wynikał tu bowiem nie tylko z właściwego im potencjału fabularnego, lecz niemal bez wyjątku z ich aktualnej obecności i popularności na ekranach kin. Co gorsza, twórcy powieści filmowych dokonują w nich swego rodzaju pisarskiej imitacji, poprzestając jedynie na rozwijaniu zaczerpniętej z popularnego pierwowzoru warstwy zdarzeniowo-fabularnej.

A zatem wartość dodana tych transferów z kina do drukarni i na półki księgarskie niemal nie występuje. Zagłębienie w lekturę takich tekstów potwierdza, że powieść filmowa - jako wyraz poetyki zrealizowanej- „upupiała" filmowy pierwowzór, generalnie dezawuujac wartości artystyczne, jakie przynajmniej część z nich (na przykład Niepotrzebny człowiek Victora Fleminga, 1927, Pod dachami Paryża René Claira, 1930, czy Cyrk Charliego Chaplina, 1928) posiadała. W produkcjach określanych mianem powieści filmowej działo się więc à rebours dokładnie tak, jak w przypadku złych, nieudolnych, imitatorskich ekranizacji dzieł literackich, w efekcie których pierwowzór tracił swój artystyczno-kulturowy potencjał sprowadzony do marnej imitacji.

Nie o taką relację kina z literaturą chodzi w omawianym studium Stefanii Zahorskiej. Jego autorka poszukuje ujęcia zdolnego ukazać bez porównania głębsze powiązania obu dziedzin. Nie utwierdza kursujących w zbiorowej świadomości stereotypów dotyczących podrzędnego statusu filmu, rzekomo niezdolnego do wykreowania i zaprezentowania własnych autonomicznych wartości: artystycznych, poznawczych etc. Kwestionując owe stereotypy, zmierza do odkrycia potencjału estetycznego wynikającego z oryginalnej ekspresji Dziesiątej Muzy, potwierdzonego jej oddziaływaniem na przemiany prozy powieściowej (eliptyczność konstrukcji czasu i przestrzeni, narracja symultaniczna, a także szczegółowość opisu wynikająca z niepowtarzalnych możliwości obiektywu kamery etc.).

Pisze na ten temat tak:

Przyznajmy, że film kształtuje zmysł konkretności, że zamienia nieuchwytne, abstrakcyjne określenia i pojęcia na widzialne obrazy, plastyczne, dotykalne, kształty. Za jego sprawą sensualizm przenika wyobraźnię. Przyznajmy też, że film zdynamizował nasz świat, ruszył go z posad. A przy tym władczo i bezwzględnie poczyna sobie z czasem: dowolnie skraca go, wydłuża, dowolnie przemieszcza zjawiska. $\mathrm{W}$ tych dziedzinach film jest istotnie reformatorem. I ulega mu nawet - dostojne słowo pisane.

Ów sensualizm przedstawień filmowych, ich pociagająca i atrakcyjna dla milionów widzów zmysłowość akcentowana przez Zahorską stanowi nie cechę występujacca fakultatywnie, lecz generalny wyznacznik. Wydobycie go na plan pierwszy i jednoczesne powiąanie z właściwościami narracji w ruchomych obrazach czyni jej koncepcję estetyki kina i sztuki 
filmowej zdumiewająco prekursorską na tle dzisiejszych trendów w rozważaniach teoretycznych nad filmem prezentowanych na przykład w książce Thomasa Elsaessera i Malte Hagenera Teoria filmu: wprowadzenie przez zmysty .

Fenomen pisarstwa krytyczno-filmowego Stefanii Zahorskiej, odkrywany dzisiaj na nowo, zasługuje na znacznie pełniejsze niż dotąd rozpoznanie. Mamy w tym przypadku do czynienia z refleksją krytyczną na najwyższym poziomie merytorycznym i pisarskim nie tylko w skali krajowej, ale również europejskiej i światowej. Zahorska myśli i pisze o kinie w sposób niezmiernie przenikliwy i nowatorski. Jej pisarstwo łączy w sobie głębię spojrzenia z przystępnościa przekazu myśli. Interesuja ją wydobywane z głębokim namysłem prowadzonego dyskursu szersze procesy ewolucji, a nie tylko bieżące artefakty do odnotowania. Autorka nie ulega przelotnym modom, których w kinie nigdy nie brak, unika też traktowania opisywanych zjawisk kultury filmowej w sposób powierzchowny.

Jest rok 1934. Od kilkunastu lat literatura polska przeżywa okres znakomitego rozwoju twórczości we wszelkich jej rodzajach i odmianach: w poezji, dramacie, w eseistyce i w prozie powieściowej. Piszą między innymi: Leśmian, Staff, Tuwim, Lechoń, Stern, Wierzyński, Pawlikowska-Jasnorzewska, Słonimski, Boy-Żeleński, Czechowicz, Jasieński, Gałczyński, Miłosz, Irzykowski, Witkiewicz, Berent, Rostworowski, Hemar, Szaniawski, Cwojdziński, Brzękowski, Kurek, Wat, Iwaszkiewicz, Kaden, Jaworski, Strug, Choromański, Krzywicka, Dąbrowska, Nałkowska, Gojawiczyńska..

Witold Gombrowicz właśnie zadebiutował zbiorem siedmiu opowiadań pod tytułem Pamiętnik z okresu dojrzewania (1933) i przystępuje do pisania Ferdydurke (fragment tej powieści ukaże się niebawem w „Skamandrze”, 1935), Boy pracuje nad tłumaczeniem kolejnych tomów $W$ poszukiwaniu straconego czasu, Nałkowska pisze powieść Granica (jej pierwodruk ukaże się w roku 1935), Witkacy po wydaniu Narkotyków (1932) kończy pisanie Szewców (1934), Juliusz Kaden-Bandrowski publikuje Mateusza Bigde (1933), Andrzej Strug Żótty krzyż (1932-1933), Jalu Kurek powieści Mount Everest 1924 (1933) i Grypa szaleje w Naprawie (1934), Michał Choromański po Zazdrości i medycynie (1933) Opowiadania dwuznaczne oraz Skandal $w$ Wesotych Bagniskach (oba 1934), a Bruno Schulz właśnie zaprezentował rewelacyjne Sklepy cynamonowe (1933).

Przyznać trzeba, że przedstawiony wyżej, niepełny przecież bilans ówczesnych dokonań literatury polskiej ${ }^{10}$ przedstawia się wręcz imponująco.

${ }^{9}$ T. Elsaesser, M Hagener, Teoria filmu: wprowadzenie przez zmysty, przeł. K. Wojnowski, Kraków 2015.

${ }^{10} \mathrm{~W}$ zestawieniu tym spośród pozycji szczególnie ważkich ze względu na swój poziom artystyczny pominięte zostało na przykład pierwsze polskie wydanie powieści Brunona 
Przywołuję ów fakt bujnego rozkwitu różnych form literackich w prozie tamtego okresu, ponieważ odgrywa on istotną rolę w kontekście egzemplifikacji, do której odwołuje się w swoim studium Zahorska: od poszukiwań imaginistów i futurystów z początku XX wieku, do Sklepów cynamonowych. Widać, że trzyma rękę na pulsie i doskonale wyczuwa tętno ówczesnych przemian literackich, nie wspominając już o tym, że doskonale zna się na filmie, z bliższą i dalszą przeszłością tej dziedziny włącznie.

Krytyka filmowa w wydaniu Stefanii Zahorskiej stanowi głęboko przemyślany system głoszonych przez nią poglądów. Widać to bardzo wyraźnie na tle jej - szerszej niż sam tylko film - praktyki krytycznej uprawianej $\mathrm{w}$ tym samym okresie równolegle w zakresie sztuk plastycznych oraz metakrytycznej refleksji nad charakterystyka przemian kultury współczesnej. Dziedziny artystyczne, o których pisze i do których się odwołuje, są różne. Pogląd na nie jednak - zintegrowany sposób podejścia do nich i prezentacji poszczególnych wybranych artefaktów bieżącego życia artystycznego przez autorkę - okazuje się jeśli nie absolutnie jednakowy, to w każdym razie bardzo zbliżony.

Nie było w polskiej publicystyce krytycznej na przestrzeni całego dwudziestolecia międzywojennego - a można $\mathrm{w}$ tym miejscu dodać $\mathrm{z}$ jeszcze większym podziwem, że również i później - nikogo, kto z taką swoboda, łatwością i finezją poruszałby się w swej działalności krytycznej między różnymi - traktowanymi na ogół jako całkiem odrębne - dziedzinami twórczości: literatura, sztukami plastycznymi, filmem.

Daje tu o sobie znać jedność punktu widzenia (resp. spojrzenia na sztukę) i jedność wyboru preferowanych wartości. Autorka nie zaciera różnic dzielących poszczególne sztuki, zwłaszcza film i literaturę; nie twierdzi, że takowych różnic nie ma. Dostrzegając homologię struktur narracyjnych kina i XX-wiecznej powieści, wydobywa natomiast funkcjonalne związki między nimi. To podejście pozwala jej z kolei nakreślić szansę i perspektywę możliwej kooperacji między nimi.

Cechą wyróżniająca system krytycznofilmowy Stefanii Zahorskiej w kontekście związków filmu i literatury jest zaawansowana spójność generalnej koncepcji. Krytyka filmowa i krytyka sztuki w jej wydaniu jest/ powinna być krytyką teoretyzująca i historyzujacca. Odkrywa zachodzące procesy i uczy je rozumieć. Dzięki niej przejścia między odmiennymi rodzajami twórczości wypadają tak naturalnie, wydając się w rozwoju autorskiego dyskursu układem naczyń połączonych.

Jasieńskiego Palę Paryż, do którego wstęp napisał Juliusz Kaden-Bandrowski. Wydanie to ukazało się nakładem Wydawnictwa „Rój” w roku 1931. 
W systemie tym kino i sztuka filmowa jako obiekt prowadzonej na bieżąco działalności recenzenckiej i studiów krytycznych nie sprowadzaja się do pewnej liczby gatunków czy tematów. Nie są też dziennikiem ocen czy świadectwem złych i dobrych cenzurek arbitralnie wystawianych poszczególnym filmom przez recenzentkę. Autorkę tego studium fascynuje ten aspekt możliwości ekspresji poznawczej, jaką oferują ruchome obrazy, który czyni film dziedziną niemożliwą do zastapienia na tle innych sztuk oraz środków komunikowania.

Przywołując metafory literackie z kręgu najnowszej powieści, metafory dynamiczne, „w ruchu”, opis postaci, narrację, przeplatanie się różnych płaszczyzn rzeczywistości Zahorska pisze:

Literatura nowoczesna patrzy na rzeczy przez powiększające szkła i z bliska, stała się analityczna i zmysłowa. Być może, że i te tendencje narodziły się w niej samoistnie, a nieprzeszczepione z filmu. Ale niewatpliwy jest udział filmu w ich podtrzymaniu, w kształtowaniu wyobraźni młodych pisarzy i czytelników. Zaraza konkretnego, sensualnego patrzenia na świat płynie z ekranu, nastraja i nastawia wyobraźnię ludzi, bezpośrednio lub pośrednio kształtuje obraz pisany.

Kino, sztuka filmowa i pojedyncze dzieło filmowe w ujęciu Stefanii Zahorskiej stanowią znaczącą strukturę strumienia myśli i uczuć, pełniącą na co dzień określone i doniosłe funkcje społeczne. Nic innego nie usprawiedliwia istnienia kinematografii jako ważnego elementu życia zbiorowego oraz wielkoprzemysłowego wytworu kultury nowoczesnej, podobnie jak potrzeby chodzenia do kina przez miliony ludzi na całym świecie.

$\mathrm{Z}$ tego względu Zahorska ustanawia w swoim eseju nowatorski na owe czasy partnerski model relacji między literaturą a filmem. Ani nie zderza ich z soba, ani też nie stawia pochopnie znaku równości między nimi. „To nie wyścig i porównanie zasług" - pisze. Przeciwnie, dostrzega odmienność i swoistość środków wyrazu, jakimi obie dysponuja, stawiając na ich kreatywne wspólistnienie i kulturową synergię. Podstawę funkcjonowania tej synergii stanowi nie sama adaptacja, lecz szczegółowo analizowane w eseju Zahorskiej przenikanie się struktur narracyjnych kina i nowego modelu powieści.

Zagadnienia estetyczne mają w świetle tej koncepcji przełożenie zarówno na socjologię sztuki, jak i antropologię kultury. W oczach autorki, miejsca wspólne estetyki obu spowinowaconych z sobą dziedzin otwieraja przed nimi szansę kooperacji. Wychodząc z tego założenia, Zahorska ani nie dezawuuje produkcji i twórczości filmowej jako od niedawna istniejącej niższej formy kultury, ani nie plasuje literatury i powieści na niedostępnym dla profanów Parnasie kulturalnym. Właśnie to pozbawione uprzedzeń rozległe spojrzenie wyróżnia jej pisarstwo na tle innych i czyni ją osobowościa krytyczną o wyrazistych i rozpoznawalnych rysach. 


\section{LITERATURA}

Bal M., Wędrujace pojęcia w naukach humanistycznych, przeł. M. Bucholz, Warszawa 2012.

Bazin A., O film nieczysty. Obrona adaptacji, przeł. B. Michałek, [w:] tegoż, Film i rzeczywistość, Warszawa 1963.

Elsaesser T., Hagener M., Teoria filmu: wprowadzenie przez zmysty, przeł. K. Wojnowski, Kraków 2015.

Giżycki M., Walka o film artystyczny w międzywojennej Polsce, Warszawa 1989.

Głowiński M., O intertekstualności, „Pamiętnik Literacki” 1989, z. 4-5.

Hendrykowski M., Wspótczesna adaptacja filmowa, Poznań 2014.

Irzykowski K., Dziesiata Muza. Zagadnienia estetyczne kina, Kraków 1924.

Jenkins H., Kultura konwergencji. Zderzenie starych i nowych mediów, przeł. M. Bernatowicz, M. Filiciak, Warszawa 2007.

Kurek J., Wspomnienia ze straży przedniej, „Kwartalnik Filmowy” 1961, nr 3.

Madej A., Między filmem a literatura. Szkic o powieści filmowej, [w:] Film polski wobec innych sztuk, red. A. Helman, A. Madej, Katowice 1979.

Otto W., Literatura i film w kulturze polskiej dwudziestolecia międzywojennego, Poznań 2007.

Stefania Zahorska, Wybór pism - reportaże, publicystyka, eseje, wybór, wstęp i oprac. A. Nasiłowska, Warszawa 2010.

Werner A., Literatura a film. Hasło problemowe w Stowniku literatury polskiej XX wieku, red. A. Brodzka, Warszawa 1992.

Zahorska S., Co powieść zawdzięcza filmowi? „Kurier Literacko-Naukowy” 1934, nr 29.

Zahorska S., Rozbój filmowy, „Wiadomości Literackie” 1936, nr 50 (682). 